\title{
Artificial wetlands and floating islands: Use of macrophytes
}

DOI: $10.46932 /$ sfjdv3n1-036

Received in: Dec 30st, 2021

Accepted in: Jan 1th, 2022

\section{Luis Alfredo Hernández Vásquez}

Estudiante de Doctorado en Ciencias Ambientales por la Universidad de Valladolid, España

Universidad Autónoma del Estado de Hidalgo

Carretera Pachuca-Tulancingo, km 4.5, C.P. 42076, Pachuca, Hidalgo, México

E-mail: alfredohv_basicas@zongolica.tecnm.mx

Francisco Prieto García

Doctor en Química por la Universidad de Valladolid, España

Universidad Autónoma del Estado de Hidalgo

Carretera Pachuca-Tulancingo, km 4.5, C.P. 42076, Pachuca, Hidalgo, México

E-mail: prietog@uaeh.edu.mx

\section{Judith Prieto Méndez}

Doctora en Ciencias Ambientales por la Universidad Autónoma del estado de Hidalgo

Universidad Autónoma del Estado de Hidalgo

Carretera Pachuca-Tulancingo, km 4.5, C.P. 42076, Pachuca, Hidalgo, México

E-mail: jprieto@uaeh.edu.mx

Alejandro Alvarado Lass-man

Instituto Tecnológico de Orizaba, Veracruz, México

E-mail: aalvaradolassman@ orizaba.tecnm.mx

Elena M. Otazo Sánchez

Doctor en Química por la Universidad de La Habana, Cuba

Universidad Autónoma del Estado de Hidalgo

Carretera Pachuca-Tulancingo, km 4.5, C.P. 42076, Pachuca, Hidalgo, México

E-mail: elenamariaotazo@gmail.com

\begin{abstract}
Constructed wetlands, including floating islands, are a suitable technology for wastewater treatment. They are low cost and respectful with the environment, which is why they are significantly beneficial for agricultural irrigation systems. One of the limiting factors in structuring efficient constructed wetlands is the choice of plant species that can tolerate and eliminate contaminants. Macrophytes have an important role, since they allow their filtration, retention and absorption, among other processes. The objective of the work has been to show the diversity of emergent and aquatic species used for the treatment, highlighting species such as Typha latifolia, Typha doingness and Eichhornia crassipes, as species of constant use. In efficiency, they manage to eliminate nutrients and organic matter in excess, as well as toxic elements such as zinc, cadmium, lead, chromium, mercury, among others, in values between 1595\%. Some studies also address emerging pollutants, showing that wetlands successfully mitigate the presence of contamination by these micro-pollutants, eliminating paracetamol, ibuprofen, caffeine and antibiotics, among others, in values of 75-99\%. Constructed wetlands are a frequent management practice for the mitigation of pollutants, the management of the biomass generated is an issue little explored and
\end{abstract}


rarely considered. It is important to highlight several works where biomass is used to feed animals, such as fertilizers, to generate building blocks and production of bioenergy through biogas.

Keywords: Macrophytes, constructed wetlands, wastewater, treatment efficiency, emerging pollutants, biomass.

\section{INTRODUCTION}

Wastewater treatment systems can remove most pollutants, they are not effective at removing certain substances that can be detected in significant amounts even after standard treatments. Given the need to refine techniques that can remove waterborne contaminants, constructed wetland systems have emerged as an effective bioremediation solution to degrade and remove contaminants. Wetland systems, as well as floating islands, arose from the observations that naturally swampy areas can filter pollutants as shown in Figure 1 and thus ensure water quality (STEFANAKIS, 2018; KOCHI et al., 2020). Floating islands are a type of man-made wetland in which emerging macrophytes are installed in floating structures and are used in phyto-purification, landscaping, and conservation projects.

Some experiences with floating islands have been evaluated in countries such as Germany, Australia, Belgium, China, Colombia, India, Italy, New Zealand, United Kingdom, Singapore, Sri Lanka, Thailand, Turkey, and Uganda. They are also named as constructed wetlands. Using constructed wetlands to purify wastewater is a cost-effective and more appropriate technology for many developing countries. This technology is respectful with the environment, they are habitats for many aquatic organisms, they provide a surface for the growth of microorganisms responsible for the filtration and adsorption of pollutants, in addition to inhibiting the growth of algae (ARTEAGA et al., 2019).

One of the important factors in structuring efficient constructed wetlands is the choice of plant species that can tolerate and remove contaminants. Macrophytes are an indispensable component for water treatment through wetlands, they provide good conditions for filtration, phytoremediation and provide a large surface area for adhered microbial growth (KADLEC and WALLACE, 2009; CARRASCO et al., 2017; STEFANAKIS, 2018).

It is also important to consider the mechanisms for removing contaminants. For example, biological nitrification-denitrification and uptake from plants are often the two most important nitrogen removal mechanisms in constructed wetlands. Microorganisms that grow in the aerobic root zone in a constructed wetland can stabilize organic compounds and nitrify ammonium to nitrate. As wastewater flows into anoxic zones within the wetland, microbe-mediated denitrification can convert nitrate to nitrogen gas which is then released to the atmosphere (KADLEC and WALLACE, 2009; VÁZQUEZ et al., 2015). 
Figure 1. Constructed floating wetland (floating islands) schematic.

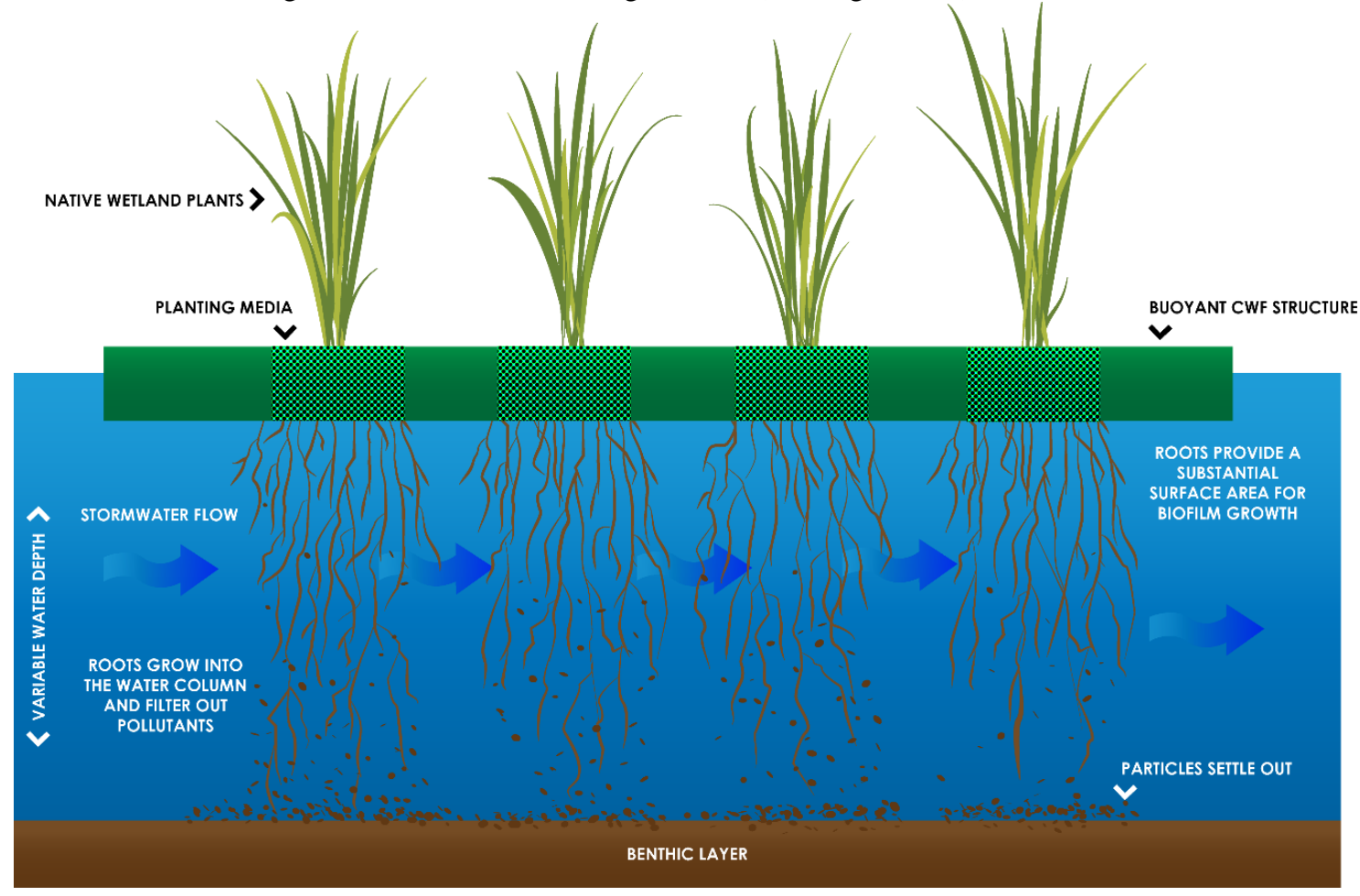

Macrophytes and their litter form a nonhomogeneous fiber bed in the wetland context. Submerged biomass additionally traps sediment in sheltered microzones, thereby lessening the potential for resuspension. The three principal mechanisms of fiber bed filtration are well known and documented in handbooks (VÁZQUEZ et al., 2015):

1. Inertial deposition or impaction-particles moving fast enough that they crash head-on into plant stems rather than being swept around by the water currents.

2. Diffusional deposition — random processes at either microscale (Brownian motion) or macroscale (bioturbation) which move a particle to an immersed surface.

3. Flow-line interception-particles moving with the water and avoiding head-on collisions but passing close enough to graze the stem and its biofilm and sticking.

Aquatic macrophytes, often also called hydrophytes, are key components of aquatic and wetland ecosystems. This work is to briefly summarizes various macrophyte classifications and covers numerous aspects of macrophytes' role in wetland ecosystems, namely in nutrient cycling. The most widely accepted macrophyte classification differentiates between freely floating macrophytes and those attached to the substrate, with the attached, or rooted macrophytes further divided into three categories: floating-leaved, submerged and emergent. The objective of this work is to briefly summarize various aspects of macrophyte classifications, and to cover in some detail, about the role of macrophytes in wetland ecosystems. 


\section{OVERVIEW OF WETLANDS}

Wetlands include swamps, bogs, lakes, and river floodplains, and can be permanently wet or flooded only during certain periods (CORZO et al., 2015). These wetland systems are of enormous ecological importance, act as filters to prevent erosion, fix large amounts of carbon, and provide habitat and food resources for a wide variety of organisms. The solution lies in the construction of new wetland systems (STEFANAKIS, 2018) and from the observation of these natural systems, artificial wetlands were designed.

Unlike natural wetlands, man-made wetlands have predetermined and controlled sizes, locations, substrate types, hydraulic conditions, and retention times. Among the advantages of constructed wetlands are their low maintenance costs compared to other water treatment facilities, their use of renewable energy resources (solar and kinetic) and natural elements (microorganisms and plants) that do not depend on complex technologies, and its ability to process large volumes of water containing different types of pollutants. Wetland systems include their sensitivity to high levels of ammonia, although sometimes, it requires occupying large space (this may be its main disadvantage in relation to other conventional systems that tend to be more compact) (KADLEC and WALLACE, 2009; CORZO et al., 2015). Nitrogen removal in constructed wetland systems is influenced by other factors, such as the presence of electron donors (biodegradable organic matter) and electron acceptors (for example, nitrate ions); this can be another limitation (MORENO \& CANO, 2021). It has been reported that to obtain these conditions, multistage treatment wetlands are required, where extensive nitrification can be obtained during the first stages under aerobic conditions, leaving then denitrification to the following anoxic/anaerobic stages. However, most of the biodegradable organic matter is oxidized in the early stages and therefore the entry to denitrification beds is often poor in readily de-gradable carbon sources (GAJEWSKA et al., 2015).

Although the use of constructed wetlands is for various types of wastewater, they have been documented as natural methods in water treatment since 1912. The United States Environmental Protection Agency (EPA, 1993) was the first to sample in the period from 1960 to 1970. In the same way, projects carried out throughout the world from 1972 to 1983 are also documented; starting in 1970, studies on the purification of nitrogen and phosphorus ( $\mathrm{N}$ and $\mathrm{P}$ ) by means of constructed wetlands began. Likewise, in the 1970s the constructed wetlands were studied to purify pesticides. During the 1990s, the purification of nutrients through artificial wetlands located in rivers was studied (EPA, 1993).

In 1967 a scale free flow system was developed. In Germany in the 1970s, Dr. Kichuth created a system called the "Root Zone Method", which consisted of a horizontal flow wetland, in which he planted P. australis, adding the combination of calcium, and iron or aluminum to cause phosphorous precipitation. In the case of the study of wetlands in the USA, the development was based on the results of European work, through the study of natural wetlands. This ecotechnology was also studied by NASA, which 
developed its own system, which they called "Hybrid treatment system" because it used anaerobic microorganisms and emerging plants (P. communis) (VYMAZAL and BŘEZINOVÁ, 2015).

Research from the last 25 years has shown positive results in terms of the construction of wetlands for the treatment of domestic and municipal wastewater, although its use for the treatment of industrial waste remains a challenge (due to its higher content of pollutants) (KADLEC and WALLACE, 2009; STEFANAKIS, 2018).

Classification of constructed wetlands is based on two parameters, that is, type of macrophytic growth and water flow regime (surface and subsurface). The constructed wetlands are classified into two type, that is, free water surface (FWS) and subsurface flow (SSF) systems. In case of FWS systems, plants are rooted in the sediment layer, and water flow is above ground (surface flow). In SSF systems, plants are rooted in a porous media such as gravels or aggregates through which water flows and treatment are accomplished. SSF systems are further divided into two types: horizontal flow SSF (HSSF) and vertical flow SSF (VSSF) (MAHMOOD et al., 2013).

\section{MACROPHYTES AND CONSTRUCTED WETLANDS}

Macrophytes, hydrophytes, halophytes and aquatic plants are terms used to designate vascular plants (angiosperms and pteridophytes) or avascular (mosses) that grow in aquatic or swampy environments. Macrophytes are classified according to their biotypes (Figure 2), reflecting their interactions with the aquatic environment as submerged, emergent, floating, free submerged, submerged rooted, submerged with floating leaves or amphibian (ROJ-ROJEWSKI et al., 2019).

The elimination of pollutants in constructed wetland systems occurs mainly due to sedimentation and biodegradation processes (STEFANIDIS and PAPASTERGIADOU, 2019). Aquatic macrophytes provide the structure to enhance flocculation and sedimentation, and the essential conditions for microbial activities to stabilize and degrade contaminants. Microbial biofilms are a group of microorganisms surrounded by a matrix of extracellular polysaccharides that remain attached to any surface, for example, contaminating and root surfaces (rhizosphere) (HERATH and VITHANAGE, 2015). Thus, the efficiency of constructed wetland systems depends mainly on two factors: the tolerance of aquatic macrophytes to pollutants present in the environment and the favoring of the growth of microorganisms present in the rhizosphere (HERATH and VITHANAGE, 2015).

Wetland systems can be characterized according to their hydrological processes, types of vegetation used and directions of flow (VYMAZAL and BŘEZINOVÁ, 2015; RAHMAN et al., 2014; SEHAR and NASSER, 2019; Pompeo, 2017), with two main types: surface flow and underground or subsurface flow, in Figure 3 the main water systems are shown wetlands in relation to the type of Macrophytes. In this figure it is observed tidal-flow, they are called Tidal-Flow Wetland Technology 
(FWT), also known as Fill and Drain and Reciprocating Technology (FAD), is an advanced wastewater treatment and reuse system that has been in development since 1993.

It is mentioned that while pteridophytes (such as Salvinia sp. and Azolla sp.) and algae (such as Cladophora sp.) Are useful, angiosperms dominate constructed wetland systems. MACHADO et al. (2017) listed the macrophytes most used in wetland constructions and pointed out that the species of the Poaceae family are the most popular, with a predominance of the species of the genus Cynodon, followed by the species Typha domingensis and T. latifolia (family Typhaceae). Some authors, however, point to the use of land plants of commercial interest, such as Agapanthus africanus (African lily), Anturium andreanum (Painter's Palette), Zantedeschia aethiopica (Arum-lily) and Strelitzia reginae (Bird of paradise flower), which they can add commercial value to wetlands and are efficient in removing waterborne pollutants (JINGYU et al., 2020).

Figure 2. Schematic representation of the different types of macrophytes and the most commonly used species in constructed wetlands and others (taken from MACHADO et al., 2017).

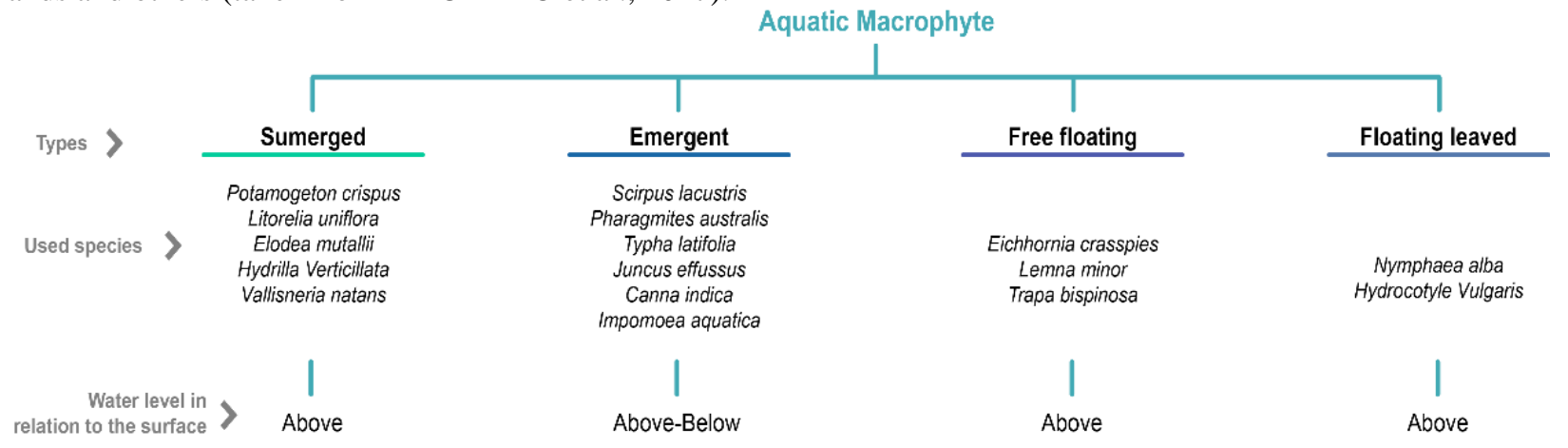

\section{CONSTRUCTED WETLANDS FOR POLLUTANTS REMOVAL}

Macrophyte use is specific to hot or cold regions and can affect the performance of a wetland. Macrophytes of cold season (for example Oenanthe decumbent) and warm season (for example Hydrilla verticillata) and the interaction between both species were evaluated in particular. Nitrogen removal was obtained from this combination, NTotal: 44.8\%, NO3-: 94\% and NH4+: 48.6\%. Therefore, it is advisable to plant Hot and Cold Climate Macrophytes in a single unit for strengthening (ZHANG et al., 2014; ZHAO et al, 2020) constructed wetlands. The role of plants in the elimination of pollutants is of utmost importance, but in recent years additional applications are being explored, of which the production of bioelectricity stands out. Studies show that it is possible to treat wastewater with Macrophytes such as Iris pseudacorus, Hyacinth pink and Phragmites australis and at the same time obtain energy. The efficiency in the removal of COD, NO3-, NH4+ was from $46.9 \%$ to $51.6 \%, 94.8 \%$ to $97.4 \%, 43.2 \%$ to $71.5 \%$, respectively. The maximum power density reached was $25.14 \mathrm{~mW} / \mathrm{m} 2$, highlighting the significant role 
of plant cultivation in the wetland matrix to strengthen bioenergy production compared to improving wastewater treatment (BARCO and BORIN, 2017; SILVAN et al., 2016).

Figure 3. Use of Macrophytes in constructed wetlands (adapted from KOCHI et al., 2020).

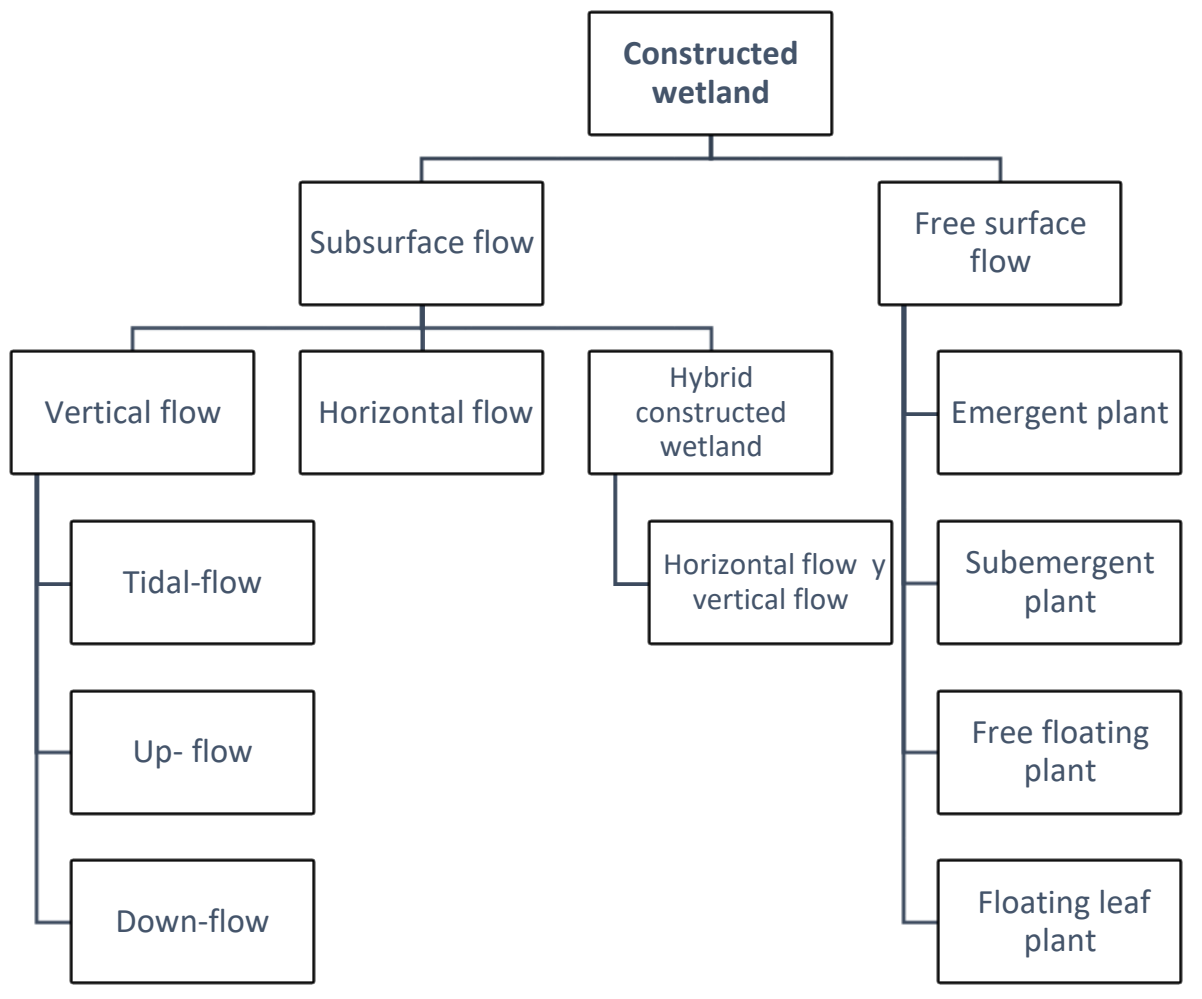

YANG et al. (2020) and QUEIROZ et al. (2020) investigated the use of macrophytes found in natural ecosystems. QUEIROZ et al. studied on the southern coast of the state of Bahia, Brazil, for wastewater treatment. Chemical oxygen demand (COD), biochemical oxygen demand (BOD), total solids (TS), $\mathrm{pH}$ and temperature were analyzed for 15 days. On the fifth day, a $74.8 \%$ decrease in BOD was achieved. With Eichhornia crassipes, COD removal was $86.4 \%$ and ST 64.3\%, for Eichhornia paniculata COD $84.8 \%$ and ST $65.18 \%$. These results indicate the potential of the genus Eichhornia for direct application in the phytoremediation of undiluted dairy wastewater with high organic loads, regardless of the use of a finite source. The degradation of surface water bodies such as rivers and lakes/ponds is one of the most important environmental problems in recent years. Bodies of water play a vital role in maintaining the microclimate of the surrounding area. The Artificial Floating Islands for nutrient removal are a viable alternative mainly in removal total nitrogen and total phosphorus. Floating island systems have been designed with Cyperus scariosus, Typha minim and Canna indica. The system with shows a better performance for total nitrogen removals obtained above 35\%. Stormwater runoff from urban or agricultural sources contains nutrients, metals, and chemical pollutants (HERRERA et al., 2016; SANDOVAL et al., 2020; ASHRAF et al., 2020). If introduced into surface waters, these contaminants can negatively impact water quality, degrading ecosystem health. NITTURKAR and BHOSALE (2019) 
examined the remediation efficacy of floating treatment wetlands planted with Canna flaccida and Juncus effusus. Plant shoots and roots were harvested, biomass was dried, ground, and analyzed for nutrient content. Juncus plants fixed $28.5 \pm 3.4 \mathrm{~g} \mathrm{~N}$ per $\mathrm{m} 2$ and $1.69 \pm 0.2 \mathrm{~g} \mathrm{P}$ per $\mathrm{m} 2$, while Canna fixed $16.8 \pm$ $2.8 \mathrm{~g} \mathrm{~N}$ per $\mathrm{m} 2$ and $1.05 \pm 0.2 \mathrm{~g} \mathrm{P}$ per $\mathrm{m} 2$. More $\mathrm{N}$ and $\mathrm{P}$ were fixed in the below mat biomass of both species than in the above mat biomass, thus whole plant harvest may be a critical management strategy for floating treatment wetlands.

The contamination of water with hydrocarbons resulting from oil exploration and production highlights the need for efficient and environmentally friendly technology to mitigate this form of water pollution. Floating treatment wetlands are a sustainable approach for remediating contaminated water (NICHOLS et al., 2016; NITTURKAR and BHOSALE. 2019). WHITE and COUSINS (2013) studied a large-scale system, they used four different plants, Phragmites australis, Typha domingensis, Leptochloa fusca, and Brachiaria mutica. The application of floating treatment wetlands to the pit reduced chemical oxygen demand, biochemical oxygen demand, total dissolved solids, hydrocarbon content, and heavy metals by $97.4 \%, 98.9 \%, 82.4 \%, 99.1 \%$, and $80 \%$, respectively, within 18 months. All plants survived and showed growth, but maximum development and biomass production were exhibited by P. australis.

The first scientifically document the in-situ establishment of an Artificial Floating Islands in a seawater port marina. The established and performance of a cork floating platform with a polyculture (Sarcocornia perennis, Juncus maritimus, Phragmites australis, Halimione portulacoides, Spartina maritima, Limonium vulgare) taking into consideration marine water characterization, with a focus on hydrocarbons. S. perennis was the species with the highest survival rate and growth. Concerning the macrofauna analysis, Mytilus sp. was the predominant taxa. This study gives new insights into broadening Artificial Floating Islands application to the saline environments of port marinas (AFZAL et al., 2019).

Horizontal flow wetlands are one of the most used alternatives for the removal of micro and macro pollutants. Thypa latifolia is one of the most used species in con-structed horizontal flow wetlands, it removes the total organic load of the effluent (BOD) between 65 to 95\%. On the other hand, it removes 70 to $75 \%$ of the electrical conductivity and the charges of various micro-pollutants among these include some compounds such as alkyphenolic metabolites of non-ionic surfactants, which are known to go through other conventional treatments without being removed. That is why this type of wetlands are a suitable alternative as tertiary treatment in a wastewater treatment plant (QUEIROZ et al., 2020).

Dairy wastewater contains large amounts of mineral and organic compounds, which can accumulate in soil and water causing serious environmental pollution. A constructed wetland is a sustainable technology for the treatment of Dairy wastewater in small-medium sized farms (CALHEIROS et al., 2020) reports a two-year study on the performance of a pilot-scale horizontal subsurface flow system covered a total surface area of $100 \mathrm{~m} 2$ and treated approximately $6 \mathrm{~m} 3$ per day. All parameters showed 
significant differences between inlet and outlet. these findings highlight the efficient use of a Constructed Wetland system for Dairy wastewater contains treatment in dairy-cattle farms.

Wetland systems are commonly used to treat waste and generally produce favorable and economically efficient results. Wetlands have also been shown to be efficient in removing total nitrogen, ammonia, nitrate, ammonium, phosphorus and reducing chemical oxygen demand (COD) from effluents, compared to others water treatment systems (ZHANG et al., 2014). Table 1 shows experiments related to the use of Macrophyte species, and the treatment efficiency of both organic and inorganic pollutants present in wastewater.

Silvan et al. (2016) investigated the implementation of free-flowing constructed wetlands operating with Typha domingensis and Eichhornia crassipes, and subsurface flow wetlands using Paspalum paniculatum and Cyperus articulatus L to remove contaminants from wastewater. The wetland that presented the highest pollutant removal efficiency from wastewater was the free-flow wetland using T. domingensis, with a removal efficiency of turbidity, color, COD, BOD5, TN, TP and TS of 97.1, 83.4, 97.8, 97.5, 97.2, 91.1 and $97.7 \%$ respectively, on the other hand, the subsurface flow wetland using P. paniculatum with removals of 94.8, 71.5, 94.7, 94.8, 92.7, 52.2 and 93\% respectively.

Macrophytes used for municipal wastewater treatment achieve macro-nutrient removals above 70\% for nitrogen and COD: $46.7 \%$. The results indicate that a hybrid-type wetland system is effective in reducing nutrients in municipal wastewater (equivalent to the contributions of a group of 1000 inhabitants) (BARCO and BORIN, 2017) and in addition to this, plant growth can be carried out effectively.

The phytoremediation potential of native macrophytic species has been shown to be very broad; various species such as Brachiaria mutica, Canna indica, Cyperus laeviga-tus, Leptochloa fusca, and Typha domingensis, manage to remove pollutants from industrial waters such as those from tanning. All the studied macrophytes significantly decreased the pollution load of tannery effluent, and the higher nutrient content of effluent stimulated their growth without any signs of negative health effects. Leptochloa fusca and T. domingensis performed better in removing pollutants and showed higher growth rates and biomass than other tested macrophytes and can be considered preferred species for use in constructed wetlands (SANDOVAL et al., 2020).

There is little attention has been given towards the use of new support or fill media for subsurface flow constructed wetlands. HERRERA et al. (2016) evaluated, during nine months, the effect of three terrestrial ornamental plants and two substrates on the elimination of pollutants in wastewaters by using fill-and-drain vertical subsurface flow. Sixteen microcosms were used, nine filled with polyethylene terephthalate (PET) and nine with porous river stone. For each type of substrate, duplicates of microcosms were used, utilizing Anthurium sp., Zantedeschia aethiopica, and Spathiphyllum wallisii as vegetation. 
Table 1. Wetland systems for pollutant removal

\begin{tabular}{|c|c|c|c|c|c|}
\hline Wetland type & Species used & Pollutant & Concentration & Removal efficiencies & Reference \\
\hline Surface flow & $\begin{array}{l}\text { Oenanthe decumbens } \\
\text { Hydrilla verticillata }\end{array}$ & $\begin{array}{c}\mathrm{TN} \\
\mathrm{NO}_{3}^{-} \\
\mathrm{NH}_{4}^{+}\end{array}$ & $\begin{array}{l}1.27 \mathrm{mg} / \mathrm{L} \\
0.28 \mathrm{mg} / \mathrm{L} \\
0.74 \mathrm{mg} / \mathrm{L}\end{array}$ & $\begin{array}{c}44.8 \% \\
94 \% \\
48.6 \%\end{array}$ & $\begin{array}{l}\text { ZANG et al., } \\
2014\end{array}$ \\
\hline Surface flow & $\begin{array}{c}\text { Eichhornia crassipes } \\
\text { Eichhornia paniculate } \\
\text { Borreria scabiosoides } \\
\text { Polygonum ferrugineum }\end{array}$ & $\begin{array}{c}\text { COD } \\
\text { BOD } \\
\text { TS }\end{array}$ & $\begin{array}{l}5,866.67 \mathrm{mg} / \mathrm{L} \\
2,282.75 \mathrm{mg} / \mathrm{L}\end{array}$ & $\begin{array}{c}86.4-84.8 \% \\
74.8 \% \\
64.3 \text { a } 65.18 \%\end{array}$ & $\begin{array}{c}\text { SILVAN et al., } \\
\text { 2016; YANG } \\
\text { et al., } 2020\end{array}$ \\
\hline Surface flow & $\begin{array}{l}\text { Cyprus scariosus } \\
\text { Typha mínima } \\
\text { Canna indica }\end{array}$ & $\begin{array}{l}\text { TP } \\
\text { TN }\end{array}$ & $\begin{array}{l}11.06 \mathrm{mg} / \mathrm{L} \\
12.3 \mathrm{mg} / \mathrm{L}\end{array}$ & $\begin{array}{l}15-22 \% \\
26-37 \%\end{array}$ & $\begin{array}{l}\text { ASHRAF et } \\
\text { al., } 2020\end{array}$ \\
\hline Surface flow & Carex appressa & $\begin{array}{c}\text { TP } \\
\text { TN } \\
\text { TSS }\end{array}$ & $\begin{array}{c}0.106 \mathrm{mg} / \mathrm{L} \\
1.33 \mathrm{mg} / \mathrm{L} \\
122.5 \mathrm{mg} / \mathrm{L}\end{array}$ & $\begin{array}{l}53 \% \\
17 \% \\
80 \%\end{array}$ & $\begin{array}{c}\text { NITTURKAR } \\
\text { and } \\
\text { BHOSALE, } \\
2019\end{array}$ \\
\hline Surface flow & $\begin{array}{l}\text { Canna flaccida } \\
\text { Juncus effusus }\end{array}$ & $\begin{array}{l}\mathrm{TP} \\
\mathrm{TN}\end{array}$ & $\begin{array}{l}0.12 \mathrm{mg} / \mathrm{L} \\
0.79 \mathrm{mg} / \mathrm{L}\end{array}$ & $\begin{array}{l}46-75 \% \\
58-84 \%\end{array}$ & $\begin{array}{l}\text { NICHOLS et } \\
\text { al., } 2016\end{array}$ \\
\hline Surface flow & $\begin{array}{c}\text { Typha domingensis } \\
\text { Phragmites australis } \\
\text { Leptochloa fusca } \\
\text { Brachiaria mutica }\end{array}$ & $\begin{array}{l}\text { COD } \\
\text { BOD } \\
\text { TSS }\end{array}$ & $\begin{array}{l}1,316 \mathrm{mg} / \mathrm{L} \\
365 \mathrm{mg} / \mathrm{L} \\
8050 \mathrm{mg} / \mathrm{L}\end{array}$ & $\begin{array}{l}97-99 \% \\
97-99 \% \\
80-82 \%\end{array}$ & $\begin{array}{l}\text { WHITE and } \\
\text { COUSINS, } \\
2013\end{array}$ \\
\hline $\begin{array}{l}\text { Horizon-tal } \\
\text { flow }\end{array}$ & $\begin{array}{c}\text { Thypa latifolia } \\
\text { Phragmites australis } \\
\text { Cyperus papyrus }\end{array}$ & $\begin{array}{l}\text { BOD } \\
\text { EC }\end{array}$ & $\begin{array}{c}292.5 \\
2,507.55 \mu \mathrm{S} / \mathrm{cm}\end{array}$ & $\begin{array}{l}66-95 \% \\
70-75 \%\end{array}$ & $\begin{array}{l}\text { QUEIROZ et } \\
\text { al., } 2020\end{array}$ \\
\hline $\begin{array}{l}\text { Horizon-tal } \\
\text { flow }\end{array}$ & $\begin{array}{l}\text { Arundo donax } L \\
\text { erus alternifolius } L\end{array}$ & $\begin{array}{c}\text { BOD } \\
\text { COD } \\
\text { TN }\end{array}$ & $\begin{array}{c}86.92 \mathrm{mg} / \mathrm{L} \\
215.29 \mathrm{mg} / \mathrm{L} \\
91 \mathrm{mg} / \mathrm{L} \\
\end{array}$ & $\begin{array}{l}76 \% \\
52 \% \\
51 \% \\
\end{array}$ & $\begin{array}{l}\text { CALHEIROS } \\
\text { et al., } 2020\end{array}$ \\
\hline Vertical flow & $\begin{array}{c}\text { Anthurium spp } \\
\text { Zantedeschia aethiopica } \\
\text { Spathiphyllum wallisii }\end{array}$ & $\begin{array}{l}\mathrm{COD} \\
\mathrm{NO}^{3-} \\
\mathrm{PO}_{4}^{-3}\end{array}$ & $\begin{array}{l}115.96 \mathrm{mg} / \mathrm{L} \\
12.08 \mathrm{mg} / \mathrm{L} \\
11.89 \mathrm{mg} / \mathrm{L}\end{array}$ & $\begin{array}{l}55-70 \% \\
28-44 \% \\
25-45 \%\end{array}$ & $\begin{array}{l}\text { HERRERA et } \\
\text { al., } 2016\end{array}$ \\
\hline Vertical flow & $\begin{array}{c}\text { Brachiaria mutica } \\
\text { Canna indica } \\
\text { Cyperus laevigatus } \\
\text { Leptochloa fusca } \\
\text { Typha domingensis }\end{array}$ & $\begin{array}{l}\mathrm{COD} \\
\mathrm{BOD} \\
\mathrm{TSS} \\
\mathrm{SO}_{4}^{2-}\end{array}$ & $\begin{array}{c}5,634 \mathrm{mg} / \mathrm{L} \\
2,910 \mathrm{mg} / \mathrm{L} \\
13,710 \mathrm{mg} / \mathrm{L} \\
1,789 \mathrm{mg} / \mathrm{L}\end{array}$ & $\begin{array}{l}39-64 \% \\
38-51 \% \\
25-49 \% \\
30-46 \%\end{array}$ & $\begin{array}{l}\text { SANDOVAL } \\
\text { et al., } 2020\end{array}$ \\
\hline Hybrid System & $\begin{array}{l}\text { Phragmites australis } \\
\text { Iris pseudacorus. }\end{array}$ & $\begin{array}{l}\mathrm{NO}_{3}^{-} \\
\mathrm{TN}^{-} \\
\mathrm{PO}_{4}^{-3}\end{array}$ & $\begin{array}{c}7.8 \mathrm{mg} / \mathrm{L} \\
21.6 \mathrm{mg} / \mathrm{L} \\
5.8 \mathrm{mg} / \mathrm{L}\end{array}$ & $\begin{array}{l}77.7 \% \\
74.3 \% \\
46.7 \%\end{array}$ & $\begin{array}{l}\text { ZHAO et al., } \\
2020\end{array}$ \\
\hline Hybrid System & $\begin{array}{l}\text { Typha domingensis, } \\
\text { Eichhornia crassipes } \\
\text { Paspalum paniculatum } \\
\text { Cyperus articulatus }\end{array}$ & $\mathrm{TP}$ & $15.8 \mathrm{mg} / \mathrm{L}$ & $\begin{array}{l}91.1 \% \\
52.2 \%\end{array}$ & $\begin{array}{l}\text { BARCO and } \\
\text { BORIN, } 2017\end{array}$ \\
\hline Hybrid System & $\begin{array}{c}\text { Iris pseudacorus, } \\
\text { Hyacinth pink } \\
\text { Phragmites australis }\end{array}$ & $\begin{array}{l}\mathrm{COD} \\
\mathrm{NH}_{4}^{+} \\
\mathrm{NO}_{3}^{-}\end{array}$ & $\begin{array}{c}210.4 \mathrm{mg} / \mathrm{L} \\
19.7 \mathrm{mg} / \mathrm{L} \\
4.78 \mathrm{mg} / \mathrm{L}\end{array}$ & $\begin{array}{c}46.9-51.6 \% \\
94.8-97.4 \% 43.2- \\
71.5 \%\end{array}$ & $\begin{array}{l}\text { SILVAN et al., } \\
2016\end{array}$ \\
\hline
\end{tabular}

TN: Total Nitrogen, NO3-: Nitrate, NH4+: Ammonium, TP: Total Phosphorus, PO4-3: Phosphate, COD: Chemical Oxygen Demand, BOD: Biological Oxygen Demand, TS: Total Solids, EC: Electrical Conductivity

The results revealed that both substrates in the were efficient in removing pollutants. The average removal of pollutants in systems with vegetation revealed a positive effect on the reduction of the biochemical oxygen demand (55-70\%), nitrates (28-44\%), phosphates (25-45\%), and fecal coliforms (52-65\%). The use of PET as a filling substrate in constructed wetlands did not affect the growth and/or the flowering of the species.

\section{HEAVY METALS REMOVAL IN CONSTRUCTED WETLANDS}

Unlike organic pollutants, heavy metals are difficult to remove from wetlands by natural action. Once they reach the sediments or water, they are easily absorbed by the roots of wetland plants and thus 
enter the food chain, posing a danger to humans and other living things through biomagnification and amplification (KADLEC and WALLACE, 2009; ASHRAF et al., 2020).

Phytoremediation is an ecologically sustainable green technology with low costs and low maintenance, which can effectively remove heavy metals from sediments and water in polluted wetlands. In addition, phytoremediation provides oxygen to the rhizosphere of wetland plants through aerenchyma from shoot to root, thus improving water quality (KOCHI et al., 2020). Table 2 shows studies related to heavy metal phytoremediation.

Heavy metals such as mercury $(\mathrm{Hg})$ pose a growing global environmental pollution problem. Due to the high toxicity of $\mathrm{Hg}$, as well as its persistence and ability to bioaccumulate and bioconcentrate, it is one of the most critical environmental problems today. Horizontal flow systems have been an alternative to remove heavy metals such as mercury $(\mathrm{Hg})$, a common mining waste. A system that incorporated Limnocharis flava was able to eliminate $90 \%$ in a period of 30 days (MARRUGO et al., 2017; LICATA et al., 2021).

LAURENCE et al. (2014) studied a wetland system for nine years that had been planted with T. latifolia and $\mathrm{P}$. australis and designed to remove cadmium $(\mathrm{Cd})$, copper $(\mathrm{Cu})$, zinc $(\mathrm{Zn})$ and lead $(\mathrm{Pb})$ derived from the surface of the road and they observed greater efficiencies in the removal of $\mathrm{Cu}(60 \%)$ and $\mathrm{Zn}(95 \%)$ than $\mathrm{Pb}(31 \%)$ or $\mathrm{Cd}(5 \%)$. These same authors mention that removal tends to decrease over time as time goes by. The accumulation of potentially toxic metals such as Zinc (Zn), Chromium (Cr) in surface water systems can cause an acute and/or chronic poison. These metals can accumulate in aquatic organisms and be magnified through food chains and eventually affect human health. The macrophage species Typha latifolia, Hydrilla verticillate and, Eichhornia crassipes have been used in surface flow wetlands, eliminating up to $23 \%$ of the $\mathrm{Zn}$ content.

TADESSE et al. (2015), XIN et al. (2020), SCHUCK and GREGER (2020) and WANG et al. (2021) investigated the phytoremediation efficiency of horizontal flow (underground) constructed wetland plant species, using industrial wastewater. Four units were raised with Cypreus alternifolius, Typha domingensis, Parawaldeckia karaka and Borassus aethiopum. The wastewater analysis showed that the $\mathrm{Cr}$ in the effluent was reduced up to $99.3 \%$ for an average input $\mathrm{Cr}$ loading rate of $40 \mathrm{mg} / \mathrm{L}$, the COD was reduced up to $80 \%$ for an organic input the load that varied between 2,202 and 8,100 $\mathrm{mg} / \mathrm{L}$ and the BOD5 was reduced up to $77 \%$ for an input organic load that varied between 650 and 1,950 $\mathrm{mg} / \mathrm{L}$. The removal of NO3- and NH3 reached 57 and 82\%, respectively. 
Table 2. Wetland systems for heavy metal removal

\begin{tabular}{|c|c|c|c|c|c|}
\hline Wetland type & Species used & Pollutant & Concentration & Removal efficiencies & Reference \\
\hline Surface flow & $\begin{array}{c}\text { Typha latifolia } \\
\text { Phragmites australis }\end{array}$ & $\begin{array}{l}\mathrm{Cu} \\
\mathrm{Zn} \\
\mathrm{Pd} \\
\mathrm{Cd}\end{array}$ & $\begin{array}{c}0.0047 \mathrm{mg} / \mathrm{L} \\
0.180 \mathrm{mg} / \mathrm{L} \\
0.063 \mathrm{mg} / \mathrm{L}\end{array}$ & $\begin{array}{c}60 \% \\
95 \% \\
31 \% \\
5 \%\end{array}$ & $\begin{array}{c}\text { MARRUGO et } \\
\text { al., } 2017\end{array}$ \\
\hline Surface flow & Pontederia cordata & $\mathrm{Cd}^{2+}$ & $0.13 \mu \mathrm{g} / \mathrm{L}$ & $93 \%$ & $\begin{array}{c}\text { MARRUGO et } \\
\text { al., } 2017\end{array}$ \\
\hline Surface flow & $\begin{array}{c}\text { Typha latifolia } \\
\text { Hydrilla verticillataand } \\
\text { Eichhornia crassipes } \\
\end{array}$ & $\mathrm{Zn}$ & 25 PPB & $23 \%$ & $\begin{array}{c}\text { LAURENCE et } \\
\text { al., } 2014\end{array}$ \\
\hline Surface flow & $\begin{array}{c}\text { Pistia stratiotes } \\
\text { Spirodela polyrhiza } \\
\text { Eichhornia crassipes }\end{array}$ & $\begin{array}{l}\mathrm{Fe} \\
\mathrm{Cu} \\
\mathrm{Ni} \\
\mathrm{Cd} \\
\mathrm{Cr} \\
\mathrm{Zn} \\
\end{array}$ & & $\begin{array}{l}83 \% \\
76 \% \\
63 \% \\
79 \% \\
63 \% \\
67 \% \\
\end{array}$ & $\begin{array}{l}\text { TADESSE et } \\
\text { al., } 2015\end{array}$ \\
\hline Surface flow & Phragmites australis & $\begin{array}{l}\mathrm{Fe} \\
\mathrm{Mn} \\
\mathrm{Ni} \\
\mathrm{Pb} \\
\mathrm{Cr}\end{array}$ & & $\begin{array}{l}96 \% \\
98 \% \\
99 \% \\
85 \% \\
99 \% \\
\end{array}$ & $\begin{array}{l}\text { TADESSE et } \\
\text { al., } 2015\end{array}$ \\
\hline Vertical flow & $\begin{array}{c}\text { Leersia } \\
\text { hexandra Swartz }\end{array}$ & $\begin{array}{l}\mathrm{Cr} \\
\mathrm{Cu} \\
\mathrm{Ni}\end{array}$ & $0.68-78 \mu \mathrm{g} / \mathrm{L}$ & $84-97 \%$ & $\begin{array}{l}\text { XIN et al., } \\
2020\end{array}$ \\
\hline Vertical flow & $\begin{array}{c}\text { Erianthus arundinaceus } \\
\text { Typha angustifolia, } \\
\text { P. australis }\end{array}$ & $\begin{array}{l}\mathrm{Cu} \\
\mathrm{Mn} \\
\mathrm{Zn} \\
\mathrm{Ni} \\
\mathrm{Cd} \\
\end{array}$ & $0.013-0.246 \mathrm{mg} / \mathrm{L}$ & $56-88 \%$ & $\begin{array}{l}\text { WANG et al., } \\
\quad 2021\end{array}$ \\
\hline Vertical flow & Alocasia puber & $\begin{array}{l}\mathrm{Cd} \\
\mathrm{Cr} \\
\mathrm{Cu} \\
\mathrm{Ni} \\
\mathrm{Zn}\end{array}$ & $\begin{array}{c}10 \mathrm{mg} / \mathrm{L} \\
100 \mathrm{mg} / \mathrm{L}\end{array}$ & $\begin{array}{r}99 \% \\
99 \% \\
99 \% \\
99 \% \\
99 \% \\
\end{array}$ & $\begin{array}{c}\text { SHAHID et al., } \\
2020\end{array}$ \\
\hline Vertical flow & $\begin{array}{l}\text { Acorus calamu } \\
\text { Canna indica }\end{array}$ & $\begin{array}{l}\mathrm{Zn} \\
\mathrm{Fe} \\
\mathrm{Cu} \\
\mathrm{Cr}\end{array}$ & $\begin{array}{l}5 \mathrm{mg} / \mathrm{L} \\
5 \mathrm{mg} / \mathrm{L} \\
5 \mathrm{mg} / \mathrm{L} \\
5 \mathrm{mg} / \mathrm{L} \\
\end{array}$ & $\begin{array}{c}89-95 \% \\
80-92 \% \\
91-96 \% \\
47-93 \% \\
\end{array}$ & $\begin{array}{l}\text { THANI et al., } \\
2019\end{array}$ \\
\hline Vertical flow & $\begin{array}{l}\text { Chlorella pyrenoidosa } \\
\text { Daphnia magna }\end{array}$ & $\begin{array}{l}\mathrm{Cd}^{2+} \\
\mathrm{Cu}^{2+}\end{array}$ & $\begin{array}{l}0.60 \mathrm{mg} / \mathrm{L} \\
0.35 \mathrm{mg} / \mathrm{L}\end{array}$ & $\begin{array}{l}82 \% \\
66 \%\end{array}$ & $\begin{array}{l}\text { BIEN et al., } \\
2020\end{array}$ \\
\hline Horizontal flow & Limnocharis flava & $\mathrm{Hg}$ & $1.50 \mu \mathrm{g} / \mathrm{mL}$ & $90 \%$ & $\begin{array}{c}\text { LICATA et al., } \\
2021\end{array}$ \\
\hline Horizontal flow & $\begin{array}{c}\text { Typha domingensis } \\
\text { Borassus aethiopum } \\
\text { Cyperus alternifolius } \\
\text { Phragmites karka }\end{array}$ & $\mathrm{Cr}$ & $40 \mathrm{mg} / \mathrm{L}$ & $\begin{array}{l}99 \% \\
99 \% \\
98 \% \\
97 \% \\
\end{array}$ & $\begin{array}{c}\text { SCHUCK and } \\
\text { GREGER, } \\
2020 \\
\end{array}$ \\
\hline Horizontal flow & $\begin{array}{c}\text { Typha latifolia Cypreus } \\
\text { papyrus }\end{array}$ & $\begin{array}{l}\mathrm{Pb} \\
\mathrm{Cu} \\
\mathrm{Mn}\end{array}$ & $\begin{array}{l}0.63 \mathrm{mg} / \mathrm{L} \\
0.49 \mathrm{mg} / \mathrm{L} \\
0.70 \mathrm{mg} / \mathrm{L}\end{array}$ & $\begin{array}{l}43 \% \\
63 \% \\
39 \%\end{array}$ & $\begin{array}{l}\text { NGUYEN et } \\
\text { al., } 2019\end{array}$ \\
\hline Hybrid System & Phragmites australis & $\begin{array}{l}\mathrm{As} \\
\mathrm{Mn} \\
\mathrm{Cd} \\
\mathrm{Zn} \\
\mathrm{Pd} \\
\end{array}$ & $\begin{array}{c}67 \mathrm{mg} / \mathrm{L} \\
1,460 \mathrm{mg} / \mathrm{L} \\
930 \mathrm{mg} / \mathrm{L} \\
245 \mathrm{mg} / \mathrm{L} \\
170 \mathrm{mg} / \mathrm{L} \\
\end{array}$ & $\begin{array}{l}80 \% \\
97 \% \\
80 \% \\
53 \% \\
39 \% \\
\end{array}$ & $\begin{array}{c}\text { BARYA et al., } \\
2020\end{array}$ \\
\hline Hybrid System & $\begin{array}{c}\text { Typha latifolia } \\
\text { Eichhornia crassipes } \\
\text { Lemna gibba } \\
\text { Pistia stratiotes }\end{array}$ & $\begin{array}{l}\mathrm{Cd} \\
\mathrm{Cu} \\
\mathrm{Pb}\end{array}$ & $\begin{array}{c}5 \mathrm{mg} / \mathrm{L} \\
10 \mathrm{mg} / \mathrm{L} \\
5 \mathrm{mg} / \mathrm{L}\end{array}$ & $\begin{array}{l}60-96 \% \\
82-90 \% \\
78-97 \%\end{array}$ & $\begin{array}{c}\text { ENGIDA et al., } \\
2020\end{array}$ \\
\hline Surface flow & Phragmites australis & $\begin{array}{l}\mathrm{As} \\
\mathrm{Cd} \\
\mathrm{Pb} \\
\mathrm{Mn} \\
\mathrm{Zn}\end{array}$ & $\begin{array}{l}1 \mathrm{mg} / \mathrm{L} \\
1 \mathrm{mg} / \mathrm{L} \\
6 \mathrm{mg} / \mathrm{L} \\
6 \mathrm{mg} / \mathrm{L} \\
6 \mathrm{mg} / \mathrm{L}\end{array}$ & $\begin{array}{c}83-89.5 \% 89.3- \\
93.3 \% 69.7-98, .0 \% \\
94.8-95.4 \% 69.2- \\
92.3 \% \\
85.3-89.1 \% 98.5- \\
98.7 \% 92.8-98.7 \% \\
95.5-96 \% 93.1- \\
96.2 \% .\end{array}$ & $\begin{array}{l}\text { AYAZ et al., } \\
2020\end{array}$ \\
\hline
\end{tabular}


Efficiency of the system, bacterial inoculation with the desired traits has appeared as an effective option (TADESSE et al., 2015) they compared the performance of four macrophytes, Brachia mutica, Typha domingensis, Phragmites australis, and Leptochala fusca, in bacterial-assisted floating treatment wetlands for the purification of five metals ( $\mathrm{Fe}, \mathrm{Mn}, \mathrm{Ni}, \mathrm{Pb}$, and $\mathrm{Cr}$ ) from contaminated river water. Finding a significant reduction in metal content. The maximum removal was observed in P. australis and inoculated with bacteria. Removing more than $95 \%$ of metals, except $85 \%$ Lead.

There is little research on HA (microcosm scale) for the synchronized removal of multiple metals. The use of floating islands with the species Pistia stratiotes, Spirodela polyrhiza and Eichhornia crassipes reduced their efficiency by removing six metals $(\mathrm{Fe}, \mathrm{Cu}, \mathrm{Cd}, \mathrm{Cr}, \mathrm{Zn}, \mathrm{Ni})$. On average managing to remove more than 79\%, E. crassipes established as the most efficient accumulator followed by P. stratiotes and S. polyrhhiza. Therefore, these wetland plants can be used to design ecological remediation of hazardous heavy metals present in wastewater (SHAID et al., 2020).

Constructed wetland microcosm by using Alocasia puber is a possible treatment method for wastewater containing heavy metals. THANI et al. (2029) used wastewater with heavy metals $\mathrm{Cd}, \mathrm{Cr}, \mathrm{Cu}$, $\mathrm{Ni}$, and $\mathrm{Zn}$ were used in this study. Several heavy metals concentrations $(5 \mathrm{mg} / \mathrm{L}, 10 \mathrm{mg} / \mathrm{L}$ and $100 \mathrm{mg} / \mathrm{L})$ were used in the systems. The results obtained showed removal efficiencies of heavy metals of $>99 \%$ after day 12.

BARYA, et al. (2020) took sewage samples collected from all cells of a domestic water treatment plant and analyzed for four heavy metals $(\mathrm{Zn}, \mathrm{Fe}, \mathrm{Cu}$, and $\mathrm{Cr}$ ). The plant species results show that the removal efficiency of the Canna indica $\mathrm{L}$. for $\mathrm{Zn}, \mathrm{Fe}, \mathrm{Cu}$, and $\mathrm{Cr}$ was 95\%, 92\%, 96\%, and $93 \%$ and Acorus calamus L. were $89 \%, 80 \%, 91 \%$, and $47 \%$ respectively. These macrophytes with the substrate (gravel and sand) have presented a wide range of tolerance to all the selected metals

NGUYE et al. (2019) this study was conducted to assess the removal of arsenic (As) and heavy metals from mining wastewater by the combination of adsorption using modified iron-ore drainage sludge, and horizontal subsurface-flow constructed wetland with common reed (Phragmites australis). The results showed that the average removals of $\mathrm{As}, \mathrm{Mn}, \mathrm{Cd}, \mathrm{Zn}$, and $\mathrm{Pb}$ by the combined system with limestone substrate for four months were $80.3 \%, 96.9 \%, 79.6 \%, 52.9 \%$, and $38.7 \%$, respectively.

ENGIDA et al. (2020) study subsurface flow constructed wetlands treatments for the treatment of floriculture industry wastewater was studied. Was assessed for physiochemical and heavy metal removal efficiency. The heavy metal concentration in the influent to effluent for $\mathrm{Pb}, \mathrm{Cu}$ and $\mathrm{Mn}$ was reduced from $0.63 \pm 0.09$ to $0.36 \pm 0.11,0.49 \pm 0.08$ to $0.18 \pm 0.05$ and $0.70 \pm 0.07$ to $0.43 \pm 0.15$, respectively. Was conducted to assess the removal efficiency of a treatment system (AYAZ et al., 2020) using sorbent and common reed (Phragmites australis). Approximately 1,400 g of sorbent that was modified from Ban Cuon iron mine drainage sludge by adding $10 \%$ sodium silicate solution and heating at $400 \mathrm{C}$ was put in a 
column of 1.81. the results showed that the removal efficiency of $\mathrm{As}, \mathrm{Cd}, \mathrm{Mn}, \mathrm{Pb}$ and $\mathrm{Zn}$ by sorbent surface constructed wetland were 83.0 - 89.5, 89.3 - 93.3, $69.7-98.0,94.8-95.4$, and $69.2-92.3 \%$, respectively; those by sorbent - subsurface constructed wetland were 85.3 - 89.1, 98.5 - 98.7, 92.8 - 98.7, 95.5 - 96.0, and $93.1-96.2 \%$. The concentrations of heavy metals in the outlet water met the National Technical Regulation on Industrial Wastewater of Vietnam

Constructed wetlands are an environmentally friendly and economically efficient sewage treatment technology, with fillers playing an important role in treatment processes. However, traditional wetland fillers (e.g., zeolite) are known to be imperfect because of their low adsorption capacity. LIU et al. (2020) investigate the adsorbent sodium titanate nano fillers (T3-F), was synthesized as an alternative to traditional filler with sodium titanate nanofibers (T3) as the raw material, epoxy adhesive as the adhesive agent and NH4HCO3 as the pore-making agent. The results showed that the adsorption of heavy metal by T3-F followed the pseudo-second-order kinetic and Langmuir isotherm models. The maximum adsorption capacities for $\mathrm{Cu} 2+, \mathrm{Pb} 2+, \mathrm{Zn} 2+, \mathrm{Cd} 2+$ were about 1.5-1.98 mmol/g, which were 4-5 times that of zeolite, the traditional commonly used filler.

\section{REMOVAL OF EMERGING POLLUTANTS IN CONSTRUCTED WETLANDS}

Emerging pollutants are compounds of different origin and chemical nature, whose presence in the environment and the possible damage they could cause, have largely gone unnoticed (ZHAO et al., 2019; RAI, 2019). It's possible polluting effects have been recently studied, approximately ten years ago when various drugs and other substances were found in the rivers of Germany that were not considered pollutants. However, they can be potentially harmful to the environment and, what is worse, they are not regulated, so it is necessary to continue with the investigations that allow us to know the impact they cause both on the environment and on the human organism (RAI, 2019).

Surface water bodies around the world can be contaminated with various pollutants. In many cases, the actual toxicity thresholds for non-target organisms are unknown, presenting unknown risks (REINOSO et al., 2017; DE OLIVEIRA et al., 2019; HWANG et al., 2020). Many of the chemicals used in daily life are eventually found in environmental compartments and many of those products expand the list of unregulated chemical compounds, known as emerging pollutants or organic micro pollutants, some pollutants are listed in Table 3. A large part of these compounds is released into surface, coastal and underground water bodies (CHEN et al., 2016). Although their concentrations in aquatic environments are generally low, they can be considered pseudo-persistent pollutants, due to their continuous release to the environment (VYSTAVNA et al., 2017).

The Surface flow systems planted with Eichornia crassipes and Vertical Flow systems planted with Heliconia rostrata removed 97 and 89\% of caffeine and ibuprofen, respectively. The performance between 
Table 3. Wetland systems for removal of emerging pollutants

\begin{tabular}{|c|c|c|c|c|c|}
\hline Wetland type & Species used & Pollutant & Concentration & $\begin{array}{c}\text { Removal } \\
\text { efficiencies }\end{array}$ & Reference \\
\hline Surface flow & Eichornia crassipes & Ibuprofen & $28 \mathrm{mg} / \mathrm{L}$ & $97 \%$ & $\begin{array}{l}\text { HWANG et al., } \\
2020\end{array}$ \\
\hline Surface flow & Canna flaccida & $\begin{array}{l}\text { Acetaminophen } \\
\text { Carbamazepine }\end{array}$ & $\begin{array}{c}5,905.5 \mu \mathrm{g} / \mathrm{mL} \\
234.5 \mu \mathrm{g} / \mathrm{mL}\end{array}$ & $\begin{array}{c}100 \% \\
73-81 \%\end{array}$ & $\begin{array}{l}\text { REINOSO et al., } \\
2017\end{array}$ \\
\hline Surface flow & $\begin{array}{c}\text { Salvinia molesta } \\
\text { Lemna minor } \\
\text { Ceratophyllum demersum } \\
\text { Elodea canadensis }\end{array}$ & $\begin{array}{l}\text { Diclofenac } \\
\text { Triclosan } \\
\text { Naproxen } \\
\text { Ibuprofen } \\
\text { Caffeine }\end{array}$ & $\begin{array}{c}0.236 \mathrm{mg} / \mathrm{mL} \\
0.315 \mathrm{mg} / \mathrm{mL} \\
0.22 \mathrm{mg} / \mathrm{mL} \\
0.021 \mathrm{mg} / \mathrm{mL} \\
0.135 \mathrm{mg} / \mathrm{mL}\end{array}$ & $\begin{array}{c}99 \% \\
96-99 \% \\
45-53 \% \\
33-48 \% \\
81-99 \%\end{array}$ & $\begin{array}{l}\text { NIVALA et al., } \\
2019\end{array}$ \\
\hline Vertical flow & Heliconia rostrata & Caffeine & $28 \mathrm{mg} / \mathrm{L}$ & $89 \%$ & $\begin{array}{l}\text { REINOSO et al., } \\
2017\end{array}$ \\
\hline Vertical flow & $\begin{array}{l}\text { Phragmites australis } \\
\text { Typha latifolia } \\
\text { Scirpus } \\
\text { sylvaticus } L .\end{array}$ & $\begin{array}{l}\text { Naproxen } \\
\text { Propranolol } \\
\text { Paracetamol } \\
\text { Caffeine }\end{array}$ & $\begin{array}{c}7.05 \mathrm{ng} / \mathrm{L} \\
3.06 \mathrm{ng} / \mathrm{L} \\
124 \mathrm{ng} / \mathrm{L} \\
1844 \mathrm{ng} / \mathrm{L}\end{array}$ & $\begin{array}{l}80 \% \\
80 \% \\
50 \% \\
50 \%\end{array}$ & CHEN et al., 2016 \\
\hline Horizontal Flow & $\begin{array}{l}\text { Heliconea Zingiberales } \\
\text { Cyperus Haspan }\end{array}$ & $\begin{array}{l}\text { Carbamazepine } \\
\text { Sildenafil } \\
\text { Methylparaben }\end{array}$ & $\begin{array}{l}10.66 \mu \mathrm{g} / \mathrm{L} \\
7.24 \mu \mathrm{g} / \mathrm{L} \\
2.64 \mu \mathrm{g} / \mathrm{L}\end{array}$ & $\begin{array}{l}95 \% \\
97 \% \\
97 \%\end{array}$ & $\begin{array}{l}\text { VYSTAVNA et al., } \\
2017\end{array}$ \\
\hline Horizontal Flow & Phragmites australis & $\begin{array}{l}\text { Naproxen } \\
\text { Oxybenzone } \\
\text { Triclosan }\end{array}$ & $\begin{array}{c}1718 \mathrm{ng} / \mathrm{L} \\
1106 \mathrm{ng} / \mathrm{L} \\
73 \mathrm{ng} / \mathrm{L}\end{array}$ & $\begin{array}{l}60 \% \\
80 \% \\
70 \%\end{array}$ & $\begin{array}{l}\text { DELGADO et } \\
\text { al.,2020 }\end{array}$ \\
\hline $\begin{array}{c}\text { Horizontal Flow } \\
\text { Surface flow }\end{array}$ & $\begin{array}{c}\text { Thalia dealbata } \\
\text { Iris tectorum }\end{array}$ & Antibiotics & 8370 ng/L & $76-99 \%$ & $\begin{array}{l}\text { DE OLIVEIRA et } \\
\text { al., } 2019\end{array}$ \\
\hline Hybrid System & Phragmites australis & $\begin{array}{l}\text { Caffeine } \\
\text { Naproxen } \\
\text { Ibuprofen } \\
\text { Benzotriazole }\end{array}$ & $\begin{array}{c}92 \mu \mathrm{g} / \mathrm{L} \\
3 \mu \mathrm{g} / \mathrm{L} \\
23 \mu \mathrm{g} / \mathrm{L} \\
14 \mu \mathrm{g} / \mathrm{L}\end{array}$ & $\begin{array}{l}100 \% \\
96 \% \\
98 \% \\
79 \% \\
\end{array}$ & $\begin{array}{l}\text { NIVALA et al., } \\
2019\end{array}$ \\
\hline Hybrid System & $\begin{array}{l}\text { Myriophyllum verticillatum } \\
\text { Pontederia cordata }\end{array}$ & $\begin{array}{c}\text { Steroid hormones } \\
\text { biocides }\end{array}$ & $\begin{array}{l}30-105 \mathrm{ng} / \mathrm{L} \\
63-515 \mathrm{ng} / \mathrm{L}\end{array}$ & $\begin{array}{l}97 \% \\
92 \%\end{array}$ & $\begin{array}{l}\text { MATAMOROS et } \\
\text { al., } 2017 \\
\end{array}$ \\
\hline
\end{tabular}

An evaluation on a mesocosm scale by HWANG et al. (2020) demonstrated the efficacy of surface wetland systems planted with Canna flaccida to remove the pollutants carbamazepine (73 to 81.8\%) and acetaminophen (100\%). Furthermore, the system planted with C. flaccida was aesthetically pleasing due to the lush flowering of the plant, the high tolerance to adverse factors, and the fact that it is only a lowlevel, local invasive species does not threaten local communities through of high reproduction and added to this the results are promising to eliminate emerging pollutants.

CHEN et al. (2016) studied the elimination of eight antibiotics including erythromycin, clarithromycin, leucomycin, sulfamethoxazole, trimethoprim, sulfamethazine, and sulphapyridine in raw domestic wastewater. These waters were treated by wetlands built on a mesocosm scale with different flow configurations. Surface flow, horizontal subsurface flow and vertical subsurface flow with Thalia dealbata and Iris tectorum plants. The aqueous removal efficiencies of the total antibiotics ranged from 75.8 to $98.6 \%$. The presence of Macrophytes was favorable for the removal of pollutants, and horizontal flow wetlands had greater removal of pollutants than surface flow. 
Pharmaceuticals in surface water are a threat to drinking water supplies. Pharmaceuticals have been detected in various environmental samples, including sewage, surface and groundwater, where they are present in trace concentrations (ranging from ng to $\mu \mathrm{g}$ per liter) and are often related to human population density in the drainage area. In recent years, concern regarding the occurrence, fate and adverse effects of these compounds has grown, since little is known about the consequences as-sociated with long term ingestion or the presence of pharmaceuticals and their residues in natural and drinking waters. The use of artificial wetlands with species such as Phragmites australis, Typha latifolia, Scirpus sylvaticus L, has shown to be efficient in the removal of Pharmaceuticals (carbamazepine, caffeine, diclofenac, estrone, ibuprofen, paracetamol, propranolol and triclosan) has a removal efficiency of 50\% to 80\% (CHEN et al., 2016).

One form of emerging pollutants, pharmaceutical and personal care products are becoming a serious problem in the discharge of domestic wastewater. Constructed wetlands have been shown to be efficient in removing two pharmaceuticals: carbamazepine and sildenafil; and a personal care product: methylparaben, present in domes-tic wastewater. Constructed wetlands have been shown to be efficient in removing two pharmaceuticals: carbamazepine and sildenafil; and a personal care product: methylparaben, present in domestic wastewater. It was determined that constructed wetlands can efficiently remove simple molecular structure compounds such as methylparaben, and complex structures such as sildenafil (efficiency up to 97\%.). However, carbamazepine remained as a recalcitrant contaminant (VYSTAVNA et al., 2017).

The discharge of emerging contaminants from wastewater treatment plants into the aquatic environment is a matter of great importance due to the potential adverse effects that they can exert on aquatic biota. the used constructed wetlands are suitable for removing emerging contaminants (Benzotriazole, 5-methylbenzotriazole, ketoprofen, naproxen, oxybenzone and diclofenac) from wastewater treatment plant effluents and, therefore, reduce the ecotoxicological effects associated with pollutant discharges (DELGADO et al., 2020).

Six pilot-scale treatment wetlands treating municipal wastewater were monitored for classical wastewater parameters and selected Emerging Organic Compounds: caf-feine, ibuprofen, naproxen, benzotriazole on a weekly basis over the course of one year. Treatment efficacy of the wetland systems was compared to that of a municipal wastewater treatment plant adjacent to the research site (activated sludge technology). The aerated wetlands and the two-stage vertical flow system showed the highest treatment efficacy (>70\% removal on a mass basis) (MATAMOROS et al., 2017).

MATAMOROS et al. (2017) Microcosm wetland systems (5 L containers) planted with Salvinia molesta, Lemna minor, Ceratophyllum demersum, and Elodea canadensis were investigated for the 
removal of diclofenac, triclosan, naproxen, ibuprofen, caffeine. After 38 days of incubation, 40-99\% of triclosan, diclofenac, and naproxen were removed from the planted and unplanted reactors.

Steroid hormones and biocides are regarded as emerging contaminants in rural wastewater in China, owing to their widespread occurrence and adverse effects on both aquatic organisms and humans. Constructed wetlands are an alternative technology for cost-effective and efficient decentralized rural sewage treatment. CHEN et al. (2019) detected five steroid hormones (ADD, AED, 19-NTD, T, and P) and four biocides (DEET, TCS, CBD, and MP) in the influent (mixture composed of domestic sew-age and livestock wastewater from a small village) in concentrations ranging from $30.5 \pm 1.25 \mathrm{ng} / \mathrm{L}$ to $105 \pm 5.14 \mathrm{ng} / \mathrm{L}$ and from $63.4 \pm 2.85 \mathrm{ng} / \mathrm{L}$ to $515 \pm 19.7 \mathrm{ng} / \mathrm{L}$, respectively. The ICW system effectively removed the detected steroid hormones $97.4 \pm 0.09 \%$ and biocides $92.4 \pm 0.54 \%$.

\section{BIOMASS MANAGEMENT OF THE WETLAND SYSTEM}

Wetland systems require defined management strategies for the collection and disposal of the biomass produced that prevent the spread of potentially invasive species, while ensuring the efficient removal of pollutants (ROJ-ROJEWSKI et al., 2019). The destination of macrophyte biomass generated by wetland systems must be well planned since its content of various pollutants must not be allowed to return to the environment. If the law allows it, biomass can be used as animal feed or fertilizer, or in the generation of bioenergy through direct combustion or to produce biogas or bioethanol. When determining the type of use of biomass, its pollutant content must be considered to avoid possible future problems related to the simple displacement of pollutants extracted from the water to the soil and other organisms. As such, priority should be given to processes that involve combustion and/or the direct use of intact biomass (such as wood).

ROJ-ROJEWSKI et al. (2019) tested the potential of some species of wetland systems to produce biogas, in light of the fact that P. australis (common reed) produces more energy than other species, and these authors noted the potential to use those systems as economically viable sources. of renewable energies. A study by Licata et al. (2019) determined that it was possible to use A. done biomass to produce bioenergy, although its profitability has not yet been determined.

Eichhornia crassipes (water hyacinth) biomass derived from a hybrid wetland system was suggested for use in civil construction by incorporating its fibers into concrete blocks (for greater strength) (LICATA et al., 2019). A similar concept was proposed for the biomass of T. latifolia, whose fibers could be used to improve the thermal and elastic properties of clay building bricks (PATEL et al., 2018). 


\section{CONCLUSIONS}

Constructed wetlands, or floating islands, appear as a promising technique for wastewater treatment. They have been studied mainly in laboratory scale experiments and most of the in-situ applications concern storm water ponds. Although artificial wetlands have a great advantage over the established options in the restoration of rivers, lakes, and others, since these can be applied without diverting the flow, they have been little studied. Artificial wetlands have great technical, economic, social and aesthetic advantages over conventional wastewater treatments, since they achieve a good quality of treated water and in addition to this, their implementation, operation and maintenance is low cost compared to conventional systems. Numerous investigations have demonstrated the important role that macrophytes play in the elimination of pollutants since they have the capacity and versatility to eliminate various pollutants, even if it is necessary to continue exploring the capacities of indigenous species. In the same way, there is a need to further explore the removal of emerging pollutants, since they are becoming more and more present. There are many commercial products (mats) available for achieving buoyancy; however, PVC pipes or natural buoyant materials (e.g., bamboo) are a reliable and cheap alternative for flotation. Most studies have used growth media in order to establish vegetation, but to the best of our knowledge, no research has been carried out investigating the potential of adding absorptive material, such as zeolite in the substratum as in the case of rooted wetlands. Research has been conducted mainly on herbaceous species and especially aquatic plants. The pollutant removal processes that take place in artificial wetland systems are: biofilm biosynthesis, sedimentation and metabolism. Settlement, caused by the root system, is the main route for the elimination of P. In recent years, additional ap-plications to water treatment are being explored, highlighting the generation of bioelectricity, the use of ornamental plants to give a better aesthetic for their subsequent commercialization, the correct management of plant biomass for the manufacture of construction material, fertilizers and Energy production. 


\section{REFERENCES}

AFZAL, M.; REHMAN, K.; SHABIR, G.; TAHSEEN, R.; IJAZ, A.; HASHMAT, A. J.; BRIX, H. Large-scale remediation of oil-contaminated water using floating treatment wetlands. NPJ Clean Water, 2(1), 1-10. 2019. https://doi.org/10.1038/s41545-018-0025-7

ARTEAGA-CORTEZ, V. M., QUEVEDO-NOLASCO, A., VAlLE-PANIAGUA, D. H. D., CASTRO-POPOCA, M., BRAVOVINAJA, Á., \& RAMÍREZ-ZIEROLD, J. A. Estado del arte: una revisión actual a los mecanismos que realizan los humedales artificiales para la remoción de nitrógeno y fósforo. Tecnología y ciencias del agua, 10(5), 319-343, 2019. https://doi.org/10.24850/j-tyca-2019-05-12

ASHRAF, S.; NAVEED, M.; AFZAL, M.; SELEIMAN, M. F.; AL-SUHAIBANI, N. A.; ZAHIR, Z. A.; ABDELLA, K. A. Unveiling the potential of novel macrophytes for the treatment of tannery effluent in vertical flow pilot constructed wetlands. Water, 12(2), 549. 2020. https://doi.org/10.3390/w12020549

AYAZ, T.; KHAN, S.; KHAN, A. Z.; LEI, M.; ALAM, M. Remediation of industrial wastewater using four hydrophyte species: A comparison of individual (pot experiments) and mix plants (constructed wetland). Journal of environmental management, 255, 109833. 2020. https://doi.org/10.1016/j.jenvman.2019.109833

BARCO, A.; BORIN, M. Treatment performance and macrophytes growth in a restored hybrid constructed wetland for municipal wastewater treatment. Ecological Engineering, 107, 160-171. 2017. https://doi.org/10.1016 / j.ecoleng.2017.07.004

BARYA, M.P.; GUPTA, D.; SHUKLA, R.; THAKUR, T.K.; MISHRA, V.K. Fitorremediación de metales pesados de aguas residuales domésticas mixtas a través de humedales de flujo vertical plantados con Canna Indica y Acorus Calamus. Current World Environment, 15 (3), 430-440. 2020. https://doi.org/10.12944/cwe.15.3.06.

BIEN, N.Q.; HOANG HA, N.T. Enhanced removal of heavy metals using sorbent and Phragmites australis. In IOP Conference Series: Earth and Environmental Science (Vol. 589). IOP Publishing Ltd. 2020. https://doi.org/10.1088/1755-1315/589/1/012012.

CALHEIROS, C. S.; CARECHO, J.; TOMASINO, M. P.; ALMEIDA, C. M. R.; MUCHA, A. P. Floating Wetland Islands Implementation and Biodiversity Assessment in a Port Marina. Water, 12(11), 3273. 2020. https://doi.org/10.3390/w12113273

CARRASCO, J. D. C. R.; DELGADO, C. Y. S.; COBOS, D. F. O. Contaminantes emergentes y su impacto en la salud. Emerging contaminants and its impact on the health. Revista de la Facultad de Ciencias Médicas de la Universidad $\begin{array}{llrl}\text { de } \quad \text { Cuenca, } & \text { 35(2), } & \text { 55-59, }\end{array}$ https://publicaciones.ucuenca.edu.ec/ojs/index.php/medicina/article/view/1723/1325

CHEN, J.; LIU, Y.S.; DENG, W. J.; YING, G.G. Removal of steroid hormones and biocides from rural wastewater by an integrated constructed wetland. Science of the Total Environment, 660, 358-365. 2019. https://doi.org/10.1016/j.scitotenv.2019.01.049

CHEN, J.; YING, G.G.; WEI, X.D.; LIU, Y.S.; LIU, S.S.; HU, L.X.; HE, L.Y.; CHEN, Z.F.; CHEN, F.R.; YANG, Y.Q. Removal of Antibiotics and Antibiotic Resistance Genes from Domestic Sewage by Constructed Wetlands: Effect of Flow Configuration and Plant Species. Sci. Total Environ. 571, 974-982. 2016. https://doi.org/10.1016/j.scitotenv.2016.04.176

CORZO, A.; SANABRIA, O.; GARCÍA, M. Optimización hidráulica de humedales artificiales de alta tasa de rellenos con medios de soporte plástico. Memorias de la III Conferencia Paname-ricana de Sistemas de Humedales para el Tratamiento y Mejoramiento de la calidad del Agua, 2016, Universidad Nacional del Litoral, Facultad de Ingeniería Química. 2016. Recuperado de http://www.fiq.unl.edu.ar. 
DE OLIVEIRA, M.; ATALLA, A.A.; FRIHLING, B.E.F.; CAVALHERI, P.S.; MIGLIOLO, L.; FILHO, F.J.C.M. Ibuprofen and Caffeine Removal in Vertical Flow and Free-Floating Macrophyte Constructed Wetlands with Heliconia Rostrata and Eichornia Crassipes. Chem. Eng. J. 373, 458-467. 2019. https://doi.org/10.1016/j.cej.2019.05.064

DELGADO, N.; BERMEO, L.; HOYOS, D. A.; PEÑUELA, G. A.; CAPPARELLI, A.; MARINO, D.; CASAS-ZAPATA, J. C. Occurrence and removal of pharmaceutical and personal care products using subsurface horizontal flow constructed wetlands. Water Research, 187, 116448. 2020. https://doi.org/10.1016/j.watres.2020.116448

ENGIDA, T.; ALEMU, T.; WU, J.; XU, D.; ZHOU, Q.; WU, Z. Analysis of constructed wetlands technology performance efficiency for the treatment of floriculture industry wastewater, in Ethiopia. Journal of Water Process Engineering, 38, 101586. 2020. https://doi.org/10.1016/j.jwpe.2020.101586

EPA, Agencia de Protección Ambiental de Estados Unidos. Guía de diseño y construc-ción de un humedal construido con flujo superficial. Región 6. Dallas, EUA: Agencia de Protección Ambiental de Estados Unidos. 1993.

GAJEWSKA, M., JÓŹWIAKOWSKI, K., GHRABI, A. and MASI, F. Impact of influent wastewater quality on nitrogen removal rates in multistage treatment wetlands. Environ Sci Pollut Res. 22:12840-12848, DOI 10.1007/s11356014-3647-4, 2015. https://doi.org/10.1007/s11356-014-3647-4

HERATH, I.; VITHANAGE, M. Phytoremediation in Constructed Wetlands. In Phytoremediation; Springer International Publishing: Cham, Switzerland. pp. 243-263. 2015. https://doi.org/10.1201/9781351067430

HERRERA-CÁRDENAS, J.; NAVARRO, A. E.; TORRES, E. Effects of porous media, macrophyte type and hydraulic retention time on the removal of organic load and micropollutants in con-structed wetlands. Journal of Environmental Science and Health, Part A, 51(5), 380-388. 2016. https://doi.org/10.1080/10934529.2015.1120512

HWANG, J. I., LI, Z., ANDREACCHIO, N., ORDONEZ HINZ, F., \& WILSON, P. C. Potential use of floating treatment wetlands established with Canna flaccida for removing organic contami-nants from surface water. International journal of phytoremediation, 22(12), 1304-1312. 2020. https://doi.org/10.1080/15226514.2020.1768511

JINGYU, H., MIWORNUNYUIE, N., EWUSI-MENSAH, D. AND ATO KOOMSON, D. Assessing the factors influencing the performance of constructed wetland-microbial fuel cell integration. Water Sci Technol, 81 (4): 631-643. 2020. https://doi.org/10.2166/wst.2020.135.

KADLEC, R. H., WALLACE, S. Treatment wetlands. Taylor \& Francis, 2nd ed. ISBN 978-1-56670-526-4. United States of America, 2009.

KOCHI, L. Y., FREITAS, P. L., MARANHO, L. T., JUNEAU, P., \& GOMES, M. P. Aquatic Macrophytes in Constructed Wetlands: A Fight against Water Pollution. Sustainability. 12(21), 9202, 2020. https://doi.org/10.3390/su12219202

LAURENCE W. GILL, PAMELA RING, BRIAN CASEY, NEIL M.P. HIGGINS, PAUL M. JOHNSTON. Long term heavy metal removal by a constructed wetland treating rainfall runoff from a motorway. Science of The Total Environment, Volumes 601-602, Pages 32-44, 2017. https://doi.org/10.1016/j.scitotenv.2017.05.182.

LAURENCE W. GILL, PAMELA RING, NEIL M.P. HIGGINS, PAUL M. JOHNSTON. Accumulation of heavy metals in a constructed wetland treating road runoff, Ecological Engineering, Volume 70, Pages 133-139, ISSN 0925-8574, 2014. https://doi.org/10.1016/j.ecoleng.2014.03.056.

LICATA, M.; GENNARO, M.C.; TUTTOLOMONDO, T.; LETO, C. La Bella, S. Research Focusing on Plant Performance in Constructed Wetlands and Agronomic Application of Treated Wastewater-A Set of Experimental Studies in Sicily (Italy). PLoS ONE, 14, e0219445. 2019. https://doi.org/10.1371/journal.pone.0219445 
LICATA, M.; RUGGERI, R.; IACUZZI, N.; VIRGA, G.; FARRUGGIA, D.; ROSSINI, F.; TUTTOLOMONDO, T. Treatment of Combined Dairy and Domestic Wastewater with Constructed Wetland System in Sicily (Italy). Pollutant Removal Efficiency and Effect of Vegetation. Water, 13(8), 1086. 2021. https://doi.org/10.3390/

w13081086

LIU, M.; LI, X.; HE, Y.; LI, H. Aquatic toxicity of heavy metal-containing wastewater effluent treated using vertical flow constructed wetlands. Science of the Total Environment, 727.2020. https://doi.org/10.1016/j.scitotenv.2020.138616.

MACHADO, A.I.; BERETTA, M.; FRAGOSO, R.; DUARTE, E. Overview of the State of the Art of Constructed Wetlands for Decentralized Wastewater Management in Brazil. J. Environ. Manag. 187, 560-570. 2017. https://doi.org/10.1016/j.jenvman.2016.11.015

MAHMOOD, Q., PERVEZ, A., SAIMA ZEB, B., ZAFFAR, H., YAQOOB, H., WASEEM, M., ZAHIDULLAH, M. AND AFSHEEN A. Natural Treatment Systems as Sustainable Ecotechnologies for the Developing Countries. BioMed Research International. Volume 2013, 19 pages. 2013. http://dx.doi.org/10.1155/2013/796373.

MARRUGO-NEGRETE, J.; ENAMORADO-MONTES, G.; DURANGO-HERNÁNDEZ, J.; PINEDO-HERNÁNDEZ, J.; DÍEZ, S. Removal of Mercury from Gold Mine Effluents Using Limnocharis Flava in Constructed Wetlands. Chemosphere.167, 188-192. 2017. https://doi.org/10.1016/j.chemosphere.2016.09.130

MATAMOROS V.; NGUYEN L.X.; ARIAS C.A.; SALVADÓ V.; BRIX H. Evaluation of aquatic plants for removing polar microcontaminants: a microcosm experiment. Chemosphere. 88(10):1257-64. 2012. https://doi.org/10.1016/j.chemosphere.2012.04.004

MATAMOROS, V.; RODRÍGUEZ, Y.; BAYONA, J. M. Mitigation of emerging contaminants by full-scale horizontal flow constructed wetlands fed with secondary treated wastewater. Eco-logical Engineering, 99, 222-227. 2017. https://doi.org/10.1016/j.ecoleng.2016.11.054.

MORENO, C. S. and CANO, T. Phenolic compounds obtained from the by-product of Persea americana Mill. for the reduction of organic matter in the effluent of a tanning industry of Tayassu pecari. South Florida Journal of Development, Vol. 2 No. 5, 2021. https://doi.org/10.46932/sfjdv2n5-062

NGUYEN, H.T.; NGUYEN, B. Q.; DUONG, T.T.; BUI, A.T.; NGUYEN, H.T.; CAO, H.T.; KIM, K. W. Pilot-scale removal of arsenic and heavy metals from mining wastewater using ad-sorption combined with constructed wetland. Minerals, 9(6), 379. 2019. https://doi.org/10.3390/min9060379

NICHOLS, P.; LUCKE, T.; DRAPPER, D.; WALKER, C. Performance evaluation of a floating treatment wetland in an urban catchment. Water, 8(6), 244. 2016.

NITTURKAR R.N.; BHOSALE S. M. Performance Evaluation of Artificial Floating Island for Nutrient Removal. International journal of engineering research \& technology (IJERT),8 (12) 113-117. 2019. http://dx.doi.org/10.17577/IJERTV8IS120022

NIVALA, J.; KAHL, S.; BOOG, J.; VAN AFFERDEN, M.; REEMTSMA, T.; MÜLLER, R.A. Dynamics of emerging organic contaminant removal in conventional and intensified subsurface flow treatment wetlands. Science of the Total Environment, 649, 1144-1156. 2019. https://doi.org/10.1016/j.scitotenv.2018.08.339

PATEL, A.G.; PAULI, M.K.; LIMA, M.X.; CARVALHO, K.Q.; PASSIG, F.H.; MACIOSKI, G. Destinação final de resíduos da macrófita Eichhornia crassipes na incorporação de blocos de concreto. Specialist Conference on Wetland Systems for Water Pollution Control, Valencia, Spain. Dis-ponible en línea: https://www.researchgate.net/publication/339054547_Final_destination_of_residues_of_ the_Eichhornia_crassipes_macrophyte_in_concrete_block_incorporation. 2018. 
POMPÊO, M. Monitoramento e Manejo de Macrófitas Aquáticas Em Reservatórios Tro-picais Brasileiros; Instituto de Biociências, Universidade de São Paulo: São Paulo, Brasil. ISBN 978-85-85658-67-0. https://doi.org/10.11606/978858565867. 2017.

QUEIROZ, R. D. C. S. D., LÔBO, I. P., RIBEIRO, V. D. S., RODRIGUES, L. B., \& ALMEIDA NETO, J. A. D. Assessment of autochthonous aquatic macrophytes with phytoremediation potential for dairy wastewater treatment in floating constructed wetlands. International journal of phy-toremediation, 22(5), 518-528. 2020. https://doi.org/10.1080/15226514.2019.1686603

RAHMAN, K.Z.; WIESSNER, A.; KUSCHK, P.; VAN AFFERDEN, M.; MATTUSCH, J.; MÜLLER, R.A. Removal and Fate of Arsenic in the Rhizosphere of Juncus Effusus Treating Artificial Wastewater in Laboratory-Scale Constructed Wetlands. Ecol. Eng. 69, 93-105. 2014. https://doi.org/10.1016/j.ecoleng.2014.03.050

RAI, P. K. Heavy metals/metalloids remediation from wastewater using free floating macrophytes of a natural wetland. Environmental Technology \& Innovation, 15, 100393. 2019. https://doi.org/10.1016/j.eti.2019.100393

REINOSO CARRASCO, J. C., SERRANO DELGADO, C. Y., ORELLANA COBOS, D. F. Contaminantes emergentes y su impacto en la salud. Revista de la Facultad de Ciencias Médicas de la Universidad de Cuenca. Volumen 35(2): 55 59. 2017. https://publicaciones.ucuenca.edu.ec/ojs/index.php/medicina/article/view/1723/1325

ROJ-ROJEWSKI, S.; WYSOCKA-CZUBASZEK, A.; CZUBASZEK, R.; KAMOCKI, A.; BANASZUK, P. Anaerobic Digestion of Wetland Biomass fromConservation Management for Biogas Production. Biomass Bioenergy.122, 126-132, 2019. https://doi.org/10.1016/j.biombioe.2019.01.038

SANDOVAL, L.; MARÍN-MUÑIZ, J. L.; ZAMORA-CASTRO, S. A.; SANDOVAL-SALAS, F.; ALVARADO-LASSMAN, A. Evaluation of wastewater treatment by microcosms of vertical subsurface wetlands in partially saturated conditions planted with ornamental plants and filled with mineral and plastic substrates. International journal of environmental research and public health, 16(2), 167. 2020. https://doi.org/10.3390/ijerph16020167

SCHUCK, M., AND GREGER, M. Plant traits related to the heavy metal removal capacities of wetland plants. International Journal of Phytoremediation. Vol. 22, No. 4, 427-435. 2020. https://doi.org/10.1080/15226514.2019.1669529.

SEHAR, S.; NASSER, H.A. Wastewater Treatment of Food Industries through Con-structed Wetland: A Review. Int. J. Environ. Sci. Technol. 16, 6453-6472. 2019. https://doi.org/10.1007/s13762-019-02472-7

SHAHID, M. J.; ALI, S.; SHABIR, G.; SIDDIQUE, M.; RIZWAN, M.; SELEIMAN, M. F.; AFZAL, M. Comparing the performance of four macrophytes in bacterial assisted floating treatment wetlands for the removal of trace metals (Fe, $\mathrm{Mn}, \mathrm{Ni}, \mathrm{Pb}$, and $\mathrm{Cr}$ ) from polluted river water. Chemosphere, 243, 125353.2020. https://doi.org/10.1016/j.chemosphere.2019.125353

SILVAN, R.S., LOPEZ OCANA, G., BAUTISTA MARGULIS, R. G., HERNANDEZ BARAJAS, J. R., and ROMELLON CERINO, $M$. J. Evaluation of free flow and subsurface wetlands in wastewater pollutant removal using different vegetation macrophyte species. Interciencia, 41(1), 40-47. 2016. https://www.interciencia.net/wpcontent/uploads/2017/10/40-LOPEZ-41-1.pdf

STEFANAKIS, A. I. Constructed Wetlands for Industrial Wastewater Treatment. Ed. John Wiley \& Sons, Ltd. UK. ISBN 978-111926834-5. P.10, 2018.

STEFANIDIS, K. AND PAPASTERGIADOU, E. Linkages between Macrophyte Functional Traits and Water Quality: Insights from a Study in Freshwater Lakes of Greece. Water 2019, 11, 1047; 2019. https://doi.org/10.3390/w11051047 
TADESSE, A.T.; SEYOUM, L.A. Evaluation of Selected Wetland Plants for Removal of Chromium from Tannery Wastewater in Constructed Wetlands, Ethiopia. Afr. J. Environ. Sci. Technol.9, 420-427. 2015. https://doi.org/10.5897/AJEST2014.1793

THANI, N. S. M.; GHAZI, R. M.; AMIN, M. F. M.; HAMZAH, Z. Phytoremediaton of heavy metals from wastewater by constructed wetland microcosm planted with alocasia puber. Jurnal Teknologi, 81(5). 2019. https://doi.org/10.11113/jt.v81.13613

VÁZQUEZ-BURNEY, R., BAYS, J., MESSER, R. AND HARRIS, J. Floating wetland islands as a method of nitrogen mass reduction: results of a 1-year test. Water Science \& Technology Volume 72, number 5, pp. 704-710, 2015. https://doi.org/10.2166/wst.2015.235

VYMAZAL, J.; BŘEZINOVÁ, T. The use constructed wetlands with horizontal sub-surface flow for various types of wastewater. Environment International, 75(2), 11-20, 2015. https://doi.org/10.1016/j.envint.2014.10.026

VYSTAVNA, Y.; FRKOVA, Z.; MARCHAND, L.; VERGELES, Y.; STOLBERG, F. Removal efficiency of pharmaceuticals in a full scale constructed wetland in East Ukraine. Ecological Engineering, 108, 50-58. 2017. https://doi.org/10.1016/j.ecoleng.2017.08.009

WANG, J., WANG, W., XIONG, J., LI, L., ZHAO, B., SOHAIL, I., \& HE, Z. A constructed wetland system with aquatic macrophytes for cleaning contaminated runoff/storm water from urban area in Florida. Journal of Environmental Management, 280, 111794. 2021. https://doi.org/10.1016/j.jenvman.2020.111794

WHITE, S. A.; COUSINS, M. M. Floating treatment wetland aided remediation of nitrogen and phosphorus from simulated stormwater runoff. Ecological Engineering, 61, 207-215. 2013. https://doi.org/10.1016/j.ecoleng.2013.09.020

XIN, J., MA, S., LI, Y., ZHAO, C., \& TIAN, R. Pontederia cordata, an ornamental aquatic macrophyte with great potential in phytoremediation of heavy-metal-contaminated wetlands. Ecotoxicology and Environmental Safety, 203, 111024. 2020. https://doi.org/10.1016/j.ecoenv.2020.111024

YANG, Y., ZHAO, Y., TANG, C., XU, L., MORGAN, D.; LIU, R. Role of macrophyte species in constructed wetlandmicrobial fuel cell for simultaneous wastewater treatment and bioenergy generation. Chemical Engineering Journal, 392, 123708. 2020. https://doi.org/10.1016/j.cej.2019.123708

ZHANG, D.Q.; JINADASA, K.B.S.N.; GERSBERG, R.M.; LIU, Y.; NG, W.J.; TAN, S.K. Application of Constructed Wetlands forWastewater Treatment in Developing Countries-A Review of Recent Developments (2000-2013). J. Environ. Manag. 141, 116-131. 2014. https://doi.org/10.1016/j.jenvman.2014.03.015

ZHAO, D., CHEN, C., LU, Q., ZHANG, M., ZHANG, H., and AN, S. Combined use of cold-season and warm-season macrophytes in floating constructed wetlands to increase nitrogen removal in the early cold season. Journal of Cleaner Production, 254, 120054. 2020. https://doi.org/10.1016/j.jclepro.2020.120054

ZHAO, M.; WANG, S.; WANG, H., QIN, P.; YANG, D.; SUN, Y.; KONG, F. Application of sodium titanate nanofibers as constructed wetland fillers for efficient removal of heavy metal ions from wastewater. Environmental Pollution, 248, 938-946. 2019. https://doi.org/10.1016/j.envpol.2019.02.040 